\title{
A Prophet in His Own Country
}

In January, 1866, the former postmaster general and treasurer of the Confederacy, John $\mathrm{H}$. Reagan, arrived at Galveston after five months of solitary confinement and imprisonment at Fort Warren in Boston harbor. But instead of receiving a hero's welcome as Texas' top-ranking Confederate official, he experienced abusive criticism. For, while at Fort Warren, he had written Texans advising them to renounce the right of secession and to recognize the abolition of slavery-already decided by force of arms-so that they could quickly become a state among equals once again and enjoy all rights and privileges under the Constitution. Otherwise, he predicted, military rule and universal Negro suffrage would surely be their lot. Texans, however, believing that he had weakened in his loyalty to them while in a Yankee prison, rejected his counsel as insincere and condemned him for his defection.

But in March, 1867, when Congress ousted all civil government in the South and placed the people under military law and carpetbagNegro rule, Texans remembered Reagan's sage advice and predictions. Quickly they recognized him as a true statesman of the people, even as a prophet. During the next thirty-eight years Reagan helped guide the destiny of Texas-as a leader of the Democratic party, as an outstanding participant in the ousting of carpetbag rule from Texas, as one of the foremost framers of the 1875 state constitution, as coauthor of the Interstate Commerce Act of 1887, and as the first chairman of the Texas Railroad Commission. Always, regardless of personal consequences, he spoke out for what he thought was right. And at his death on March 6,1905, even in his own country he was Not Without Honor. 
THIS PAGE INTENTIONALLY LEFT BLANK 